\title{
Hormonal control of glucose homoeostasis in ruminants
}

\author{
By G. H. McDoweld, Dairy Research Unit, Department of Animal Husbandry, \\ University of Syndey, Camden, NSW, 2570, Australia
}

Little, if any, glucose is absorbed from the alimentary tract of the grazing ruminant and it appears that significant absorption of glucose only occurs in ruminants consuming relatively large amounts of grain (Bergman, 1973; Lindsay, 1978). In spite of this, ruminants have an absolute requirement for glucose which is similar to that of nonruminants. Certainly glucose is an essential metabolite for the brain as there is no oxidation of ketones in the brain of the ruminant (Lindsay, 1980). Moreover, glucose is required for turnover and synthesis of fat, as a precursor of muscle glycogen and in pregnant and lactating ruminants, glucose is an essential metabolite. Indeed the glucose requirements of late-pregnant and lactating ruminants increase dramatically beyond that required for maintenance (Bergman, 1973, see also Table 2, p. 164).

It is not surprising that volatile fatty acids derived from rumen fermentation of carbohydrate provide some $70 \%$ of the energy requirements of the ruminant (Bergman, I973). Even so, gluconeogenesis and the maintenance of glucose homoeostasis are critical processes in view of the absolute requirements for glucose.

Unlike the situation in monogastric species, gluconeogenesis is maximal after feed ingestion and decreases during food restriction. The major factor influencing the rate of gluconeogenesis is the availability of substrates (Lindsay, 1978). In fed ruminants the principal precursors are propionate and amino acids, with lactate and glycerol making minor contributions to glucose production. During fasting, propionate supply is reduced to negligible quantities such that glycerol and amino acids from adipose and muscle tissue respectively are major precursors of glucose (Bergman, 1973). Some $85-90 \%$ of glucose production occurs in the liver and the remainder is synthesized in the kidney (Bergman, 1973; Lindsay, 1978).

Ruminants are able to spare glucose by utilizing alternative substrates for oxidative purposes. Under normal conditions, acetate is an important oxidative fuel (Lindsay, 1959) and the contribution of acetate to oxidative metabolism increases markedly under conditions where energy requirements increase (Bird et al. I981). Similarly, glucose sparing may be effected by utilizing free fatty acids (FFA) as oxidative substrates when energy requirements increase (Bird et al. 1981; Pethick \& Lindsay, 198I).

In considering the control of glucose homoeostasis in the ruminant it is necessary to consider the control of glucose production and its utilization in the body as well as the control of the supply of alternative energy substrates. During the last decade or so an increasing body of information on the means by which 
hormones effect control over these processes has been gathered from studies on ruminants.

\section{Insulin and glucagon}

There is unequivocal evidence that insulin and glucagon are critical for the maintenance of glucose homoeostasis in ruminants, just as they are in monogastric species (Exton, 1979; Felig et al. 1979). A number of excellent reviews on the roles of insulin and glucagon in the maintenance of glucose homoeostasis in ruminants has been published in recent years. In view of this, no attempt will be made here to provide a detailed account of the effects of insulin and glucagon. Instead, a brief summary of their participation will be given and readers are referred to the reviews by Bassett (1975, 1978), Brockman (1978) and Trenkle (1978, 1981).

Insulin is the most important regulator of glucose disposal and production. It inhibits gluconeogenesis and the output of glucose from the liver, apparently increases uptake and the incorporation of amino acids into muscle protein and promotes lipogenesis in adipose tissue. As a result of these actions of insulin, glucose production is reduced, its utilization by peripheral tissues is promoted (indeed administration of exogenous insulin to ruminants induces hypoglycaemia) and the supplies of alternative energy substrates such as acetate and FFA are reduced. Although it has been assumed that ruminants are less sensitive to the effects of insulin than monogastric species (see Trenkle, $198 \mathrm{I}$ ), it has been pointed out that diabetes (induced by, for example, alloxan treatment or by pancreatectomy) results in aberrations in glucose metabolism just as severe as those seen in monogastric species (see Bassett, 1978).

Glucagon acts to balance the effects of insulin and thus maintain glucose homoeostasis. It acts primarily to increase hepatic glucose output by promoting gluconeogenesis from amino acids and other glucose precursors, such as lactate and propionate, and by promoting hepatic glycogenolysis. Although the principal effects of glucagon appear to be exerted on the liver, in situations where glucagon concentrations are increased artificially and/or where insulin secretion is suppressed, glucagon may participate by facilitating lipolysis in adipose tissue.

Some time ago, Unger (1971) suggested that the molar ratio of insulin: glucagon may be of greater physiological significance than the absolute concentrations of the two hormones in maintaining glucose homoeostasis. Subsequently, Bassett (1975) pointed out that molar ratios of insulin:glucagon in ruminants would be low in view of the paucity of alimentary glucose. None the less, Bassett (1975) suggested that the molar ratio of insulin:glucagon is of significance for controlling gluconeogenesis in ruminants.

In connection with the latter, results of recent studies with lactating sheep submitted to a severe reduction in feed intake, illustrate that the relationship between insulin and glucagon is of importance in maintaining glucose homoeostasis (see Gow et al. 1981). In these studies feed intake was decreased by $80 \%$ for $4 \mathrm{~d}$. As might be expected, food deprivation reduced glucose supply. Concentrations of plasma insulin (but not glucagon) decreased resulting in a 


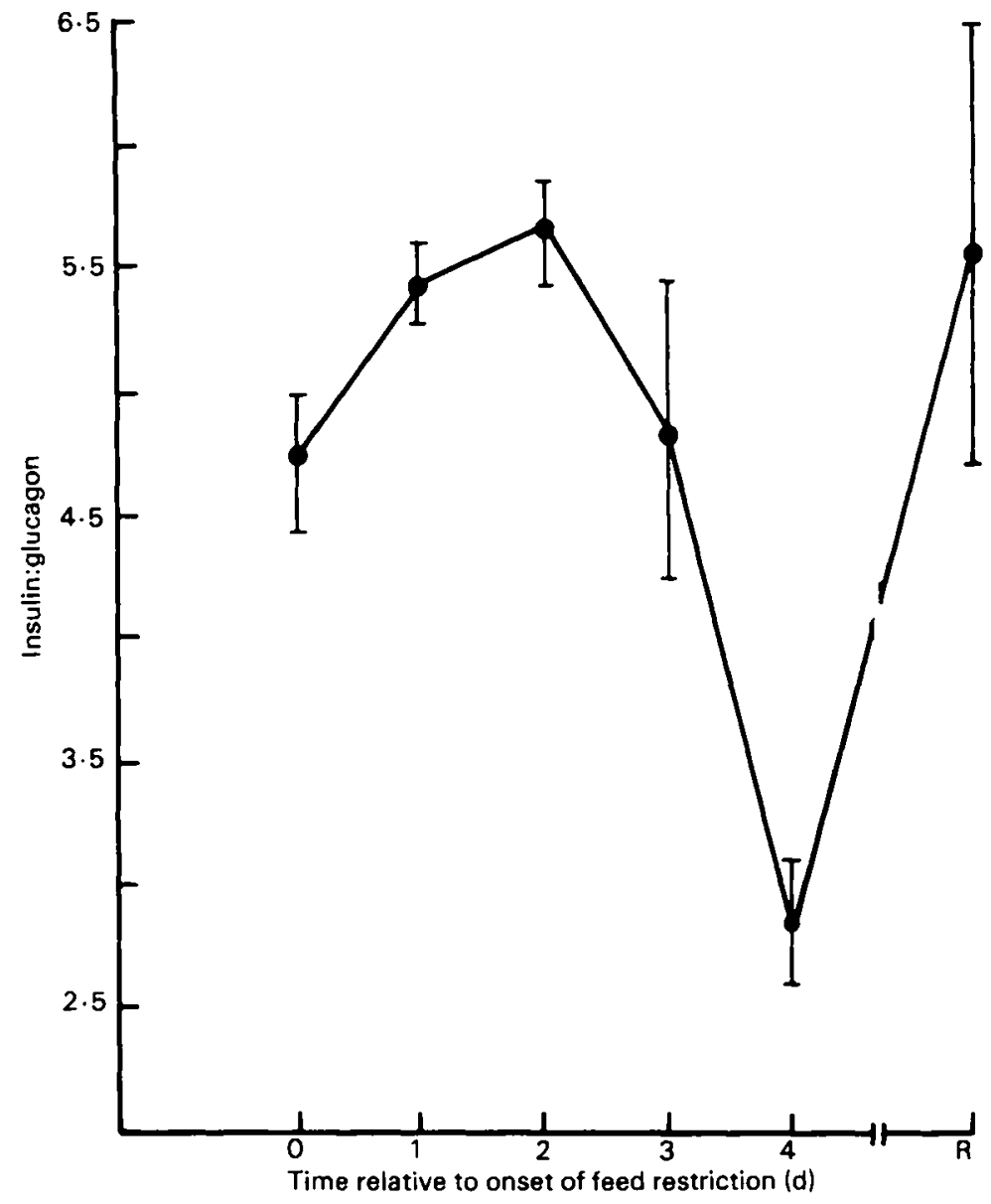

Fig. I. The molar ratio of insulin:glucagon before, during and $10-14 \mathrm{~d}$ after restoring food intake $(\mathbf{R})$ in lactating ewes submitted to food restriction. Ewes were given initially a mixture of lucerne chaff and rolled barley in sufficient quantities to meet calculated energy requirements for maintenance plus milk production. During a period of $4 \mathrm{~d}$, food intake was reduced to $20 \%$ of this basal quantity. For each ewe, insulin and glucagon were measured in a plasma sample prepared by pooling samples collected on each day. Values presented are means for four ewes and standard errors are shown as vertical bars.

substantial decrease in the molar ratio of insulin:glucagon from about 6 to 3 by the fourth day of food deprivation (see Fig. I). Plasma concentrations of most glucogenic amino acids decreased significantly during food restriction. This suggests that the relative dominance of glucagon over insulin resulted in promotion of hepatic utilization of amino acids released from tissue protein for gluconeogenesis.

\section{Growth hormone}

Characteristically, concentrations of growth hormone in the plasma of ruminants are extremely variable due to episodic release of the hormone (Bassett, 1974; Hart, Flux et al. 1975; Tindal et al. 1978). In spite of this there are profound effects of nutrient intake on concentrations of plasma growth hormone in 
ruminants. Thus it appears that plasma concentrations of growth hormone are inversely related to food (energy) intake (Trenkle, I970; Bassett et al. 1971; Hove \& Blom, 1973). Certainly, in ruminants deprived of food, concentrations of growth hormone increase (Bassett, 1974; Gow et al. 1981). Moreover, in lactating cows, plasma concentrations of growth hormone are greater in high- than in lowproducing animals fed similarly (Hart, Bines et al. 1975, 1980) and lambs given restricted amounts of feed have higher concentrations of plasma growth hormone than lambs fed ad lib. (Forbes et al. 1979).

The above observations suggest that growth hormone plays a role in the maintenance of supply of energy-yielding nutrients in the ruminant. Indeed, Machlin (1976) listed a number of biological effects of growth hormone which may influence glucose homoeostasis. These included its effects in (a) promoting uptake and incorporation of amino acids into protein, (b) promoting oxidation of fatty acids and the release of fatty acids from adipose tissue and (c) antagonizing the effects of insulin and increasing the concentration of plasma glucose. Although Machlin ( 1976 ) considered that growth hormone promoted gluconeogenesis, there have been no convincing demonstrations of this effect (see p. I54). It appears that the increase in plasma glucose concentration may be due, at least in part, to the effects of growth hormone in antagonizing the effects of insulin and promoting lipolysis (Wallace \& Bassett, 1966; Bassett, 1978).

Studies where growth hormone has been administered to ruminants have demonstrated its 'diabetogenic' and 'lipolytic' effects. Subcutaneous injections of growth hormone into castrated male goats alter insulin tolerance and lipolytic material has been isolated from preparations of bovine growth hormone submitted to ion-exchange chromatography (I. C. Hart, personal communication).

Previous studies with non-lactating ewes suggested diabetogenic effects of growth hormone in the sheep (Wallace \& Bassett, 1966). Daily subcutaneous injections of ovine growth hormone over a period of 4 weeks led to marked and persistent increases in concentrations of plasma glucose and insulin. It appeared that injections of growth hormone had inhibited the effects of insulin in promoting peripheral glucose utilization.

In other studies by Bassett \& Wallace ( 1966 ), lipolytic and diabetogenic effects of growth hormone were apparent. They found that rapid intravenous injection of ovine growth hormone in mature wethers and non-lactating ewes resulted in an initial decrease in circulating levels of FFA and ketone bodies and subsequently to sustained elevations in the concentrations of these metabolites. Changes in concentrations of plasma glucose were affected by prior nutrition of the sheep. In animals given a restricted ration prior to growth hormone injection, changes in glucose were minimal. On the other hand, in adequately-fed sheep, plasma glucose decreased immediately after injection of growth hormone, then increased substantially and remained above basal levels for a prolonged period. The biphasic response of plasma glucose in the adequately-fed sheep was attributed to an initial promotion of insulin secretion followed by inhibitory effects of growth hormone on glucose utilization by muscle and adipose tissue. In connection with the latter, 
Vernon (1978) reported that growth hormone antagonized the stimulatory effects of insulin on lipogenesis from acetate and glucose in sheep adipose tissue in vitro.

Most researchers have observed substantial variations in plasma concentrations of growth hormone in ruminants associated with feeding-particularly when feeding occurs once or twice daily. Under these situations concentrations of growth hormone decrease at the time of feeding, remaining low for several hours before increasing substantially prior to the time of the next feed (Bassett, I974; Hart, Flux et al. 1975; Bines \& Hart, 1977; Driver \& Forbes, 1978; Driver et al. 1979).

Although it is tempting to correlate the changes in plasma growth hormone to plasma levels of metabolites, it has been observed that these changes occur in adequately-fed animals. Results of recent studies in goats by Tindal et al. (1982) suggest that the decrease in plasma growth hormone at the time of feeding is a neurally-effected response stimulated by stretch receptors in the cranial rumen. Indeed, inflation of a balloon placed within the rumen dramatically reduced, and deflation of the balloon rapidly increased, plasma concentrations of growth hormone. Tindal et al. (1982) also noted that plasma concentrations decreased in goats anticipating a feed. Thus, control of growth hormone secretion may be effected neurally as well as by circulating metabolites.

In connection with the latter, Hertelendy \& Kipnis (1973) observed an inverse correlation between plasma concentrations of FFA and growth hormone in sheep and speculated that a decrease in plasma concentrations of FFA may constitute the signal for release of growth hormone. Similarly, Reynaert et al. (1976) considered that a sharp decrease in plasma concentrations of FFA provided the stimulus for release of growth hormone in cattle. On the other hand, observations made in lactating cows (Reynaert et al. 1972), lactating ewes (D. Leenanuruksa and G. H. McDowell, unpublished results) and wethers (Trenkle, 1971) suggest that growth hormone may be released when a rapid decrease in plasma glucose occurs.

Results of studies with lactating cows have shown that subcutaneous injections of growth hormone substantially increase milk production (Machlin, 1973; Bines et al. 1980; Peel et al. 1981). Similarly, exogenous ovine growth hormone increases milk yield in lactating goats (Hart, Lawrence et al. 1980; Mepham et al. 1983) and ewes (Dracy \& Jordan, 1954; Jordan \& Shaffhausen, 1954; G. H. McDowell and I. C. Hart, unpublished results).

In the studies of Bines et al. (1980) high-producing (Friesian) and low-producing (Hereford cross) cows were used. In both types of cow, injections of growth hormone elicited an increase in plasma insulin and this apparently accounted for the failure to observe obvious lipolytic effects of growth hormone. No significant changes in plasma glucose were observed in the high-yielding cows but there was a significant increase in plasma-glucose concentration in the lowyielding cows. The increased yields of milk observed in these studies could be explained by an increase in the supply of energy-yielding substrates. The absence of an increased plasma glucose in the high-yielding cows presumably reflected increased utilization of glucose for milk biosynthesis. Similar observations on the 
effects of growth hormone injections on plasma glucose were recorded in highyielding cows by Peel et al. ( $198 \mathrm{I}$ ). Interestingly, the latter workers recorded a significant increase in plasma FFA.

Although Bines et al. (1980) and Peel et al. (1981) were unable to draw firm conclusions on the effects of growth hormone on glucose supply, they raised the possibilities that growth hormone may have promoted gluconeogenesis and/or spared utilization of glucose by tissues other than the mammary gland as a result of provision of alternative energy-yielding substrates. Clearly, it will be necessary for measurements to be made of the effects of growth hormone on production and utilization of glucose.

The relationship between concentrations of insulin and growth hormone (viz the ratio of insulin:growth hormone) appears to be an important determinant of nutrient availability generally and probably glucose availability in particular. A low insulin:growth hormone prevents utilization of energy-yielding nutrients in skeletal muscle and adipose tissue (Trenkle, 1978). In this connection, low ratios of insulin:growth hormone have been recorded in high-producing dairy cows (Hart, Bines $e t$ al. 1980) and in lactating ewes suddenly submitted to severe deprivation of food (Gow et al. 1981). In both of these situations there would have been a requirement for energy-yielding substrates. On the other hand, Bassett ( $\left.198_{3}\right)$ has recorded an increased insulin:growth hormone in ewes during the early stages of mammary involution induced by abrupt weaning of lambs-a situation where the requirement for energy-yielding substrates was reduced rapidly.

From the foregoing it seems reasonable to conclude that, in ruminants, growth hormone is important in the maintenance of glucose homoeostasis just as it is in monogastrics (Exton, 1979). Whether the effects of growth hormone on glucose availability are direct (promoting gluconeogenesis) or indirect (sparing glucose utilization and/or promoting the supply of alternative energy substrates) remains to be demonstrated. None the less, it appears that growth hormone does inhibit peripheral utilization of glucose (Wallace \& Bassett, 1966) by virtue of its diabetogenic effects and its lipolytic effects would provide FFA and perhaps ketones as alternative energy substrates to glucose.

\section{Catecholamines}

In common with the actions of catecholamines in man and laboratory animals (see Exton, 1979), adrenaline and noradrenaline exert profound effects on glucose homoeostasis in ruminants. Thus in ruminants catecholamines inhibit insulin secretion, promote glycogenolysis and lipolysis, stimulate glucagon secretion and increase gluconeogenesis (Bassett, 1970, 1971, 1975; Sato, 1977; Graham \& Phillips, 1981). The end result of these diverse effects of catecholamines is to increase glucose supply with a subsequent rise in plasma glucose concentration.

In studies on ruminants no measurements of peripheral concentrations of catecholamines have been made. Consequently, it is not possible to relate responses observed to 'physiological increases' in catecholamines found in vivo. Results of studies in other species have suggested that the effects of 

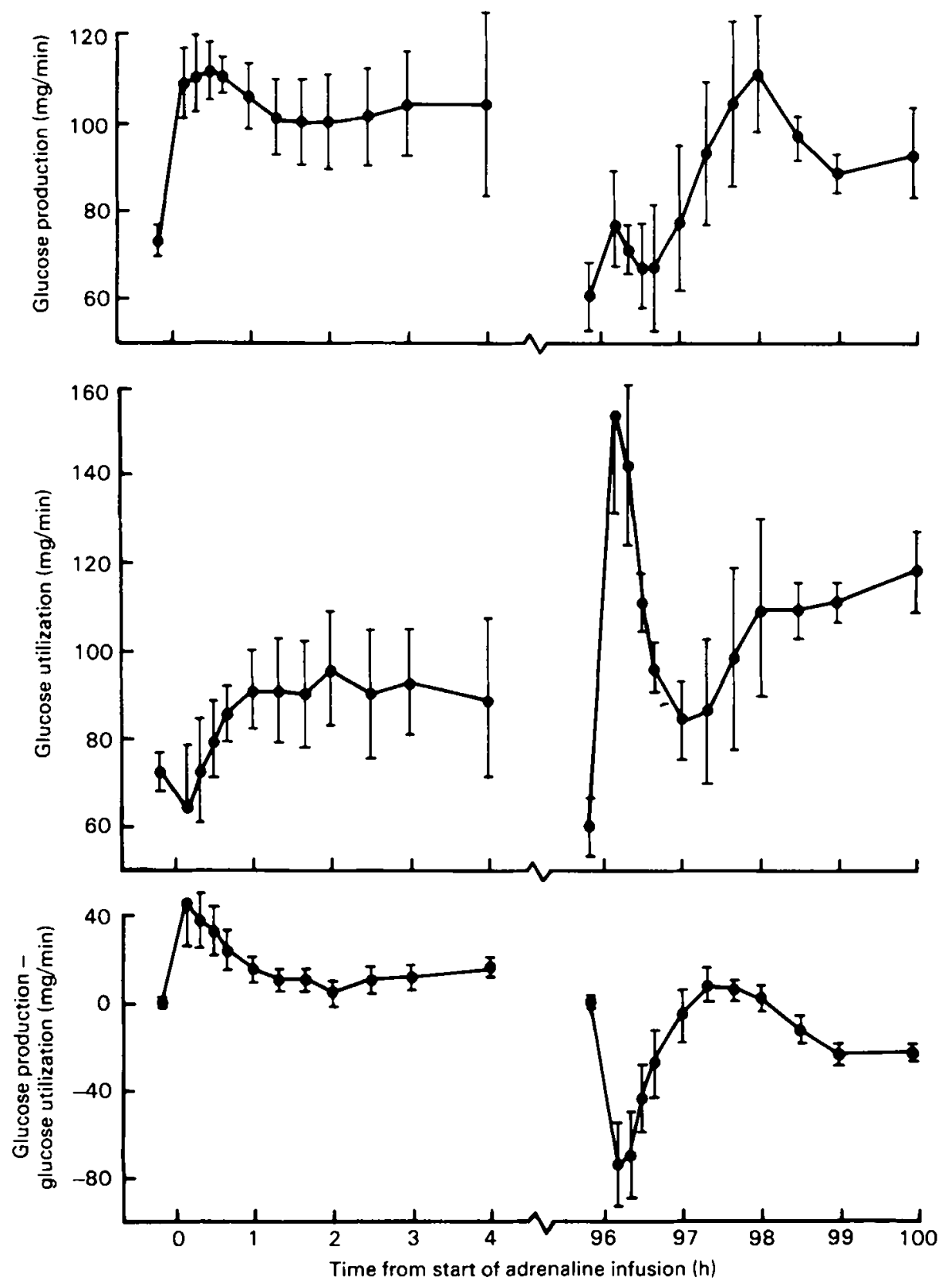

Fig. 2. Changes in glucose production and utilization in lactating ewes at the beginning and end of a period of $4 \mathrm{~d}$ over which adrenaline was infused intravenously at the rate of $0.05 \mu \mathrm{g} / \mathrm{kg}$ bodyweight per min. Values presented are means for four ewes and standard errors are shown as vertical bars. 
catecholamines occur at supra-physiological concentrations, suggesting that under normal conditions the effects of the catecholamines are mediated by catecholamines released from nerve endings rather than the adrenal medulla (Exton, 1979). Significantly, adrenaline is much more potent than noradrenaline in affecting glucose homoeostasis in the ruminant (Bassett, 1970).

Most investigations on the effects of catecholamines on glucose homoeostasis in ruminants have concentrated on the effects of administration of adrenaline and/or noradrenaline over relatively short periods. A study on the effects of prolonged intravenous infusion of adrenaline into lactating ewes was completed recently in Camden, Australia (D. Leenanuruksa and G. H. McDowell, unpublished results) and the results of this study are presented here as a demonstration of the effects of adrenaline on glucose homoeostasis in the ruminant.

Lactating ewes were given continuously a pelleted diet of barley grain, lucerne chaff and oaten chaff in sufficient amounts to meet their energy requirements for maintenance plus milk production. Over consecutive periods of $4 \mathrm{~d}$ ewes were given continuous infusions of saline ( $9 \mathrm{~g}$ sodium chloride/l), $0.05 \mathrm{\mu g}$ adrenaline $/ \mathrm{kg}$ body-weight per min and then, finally, saline. Glucose kinetics were monitored at the commencement and after withdrawal of adrenaline infusions using the procedures developed by Steele and co-workers (Steele et al. 1956; Wall et al. 1957; Steele, 1959; de Bodo et al. 1969) and subsequently modified by Cowan \& Hetenyi (I97I). Concentrations of plasma insulin and growth hormone, as well as lactate and FFA were monitored.

The effects of adrenaline infusions on glucose production and utilization are depicted in Fig. 2. Glucose production increased significantly $(\boldsymbol{P}<0.05)$ within ro min of commencing the adrenaline infusion and remained elevated over the first $5 \mathrm{~h}$ of infusion. At the end of the period of adrenaline infusion glucose production had decreased to be significantly lower $(P<0.05)$ than prior to commencement of infusion but, within an hour of withdrawal of adrenaline, glucose production increased significantly $(P<0.05)$.

Changes in the rates of glucose utilization were observed at the commencement and end of the period of adrenaline infusion. There was an apparent increase in glucose utilization which was not significant $(P>0.05)$ during the first $4 \mathrm{~h}$ of adrenaline infusion. When adrenaline was withdrawn there was a dramatic increase in glucose utilization such that by 10 min glucose utilization had increased significantly $(P<0.05)$.

These changes in glucose production and utilization were reflected by changes in concentrations of plasma glucose. During the adrenaline infusion, plasma-glucose concentrations were significantly $(P<0.05)$ increased. Concentrations rose from approximately $65 \mathrm{mg} / \mathrm{r} 00 \mathrm{ml}$ to reach peak values of approximately $100 \mathrm{mg} / 100 \mathrm{ml}$ during the first day of infusion. Values then fell to relatively stable levels of approximately $80 \mathrm{mg} / \mathrm{r} 00 \mathrm{ml}$ for the remainder of the infusion period. Immediately after withdrawal of adrenaline, plasma glucose concentrations began to fall and by $40 \mathrm{~min}$ had decreased to significantly lower $(P<0.05)$ levels of approximately 
$55 \mathrm{mg} / 100 \mathrm{ml}$. Thereafter glucose concentrations rose to relatively stable values of approximately $65 \mathrm{mg} / 100 \mathrm{ml}$.

Adrenaline infusions elicited marked changes in the plasma concentrations of FFA and lactate. Concentrations of FFA increased from basal values of approximately 5 to $10 \mathrm{mg} / 100 \mathrm{ml}$ within $30 \mathrm{~min}$, then concentrations declined to approach basal values by $4 \mathrm{~h}$. The changes in plasma lactate occurred somewhat more slowly such that concentrations increased gradually from approximately $\mathrm{I}$ to $5 \mathrm{mg} / 100 \mathrm{ml}$ by $4 \mathrm{~h}$, after which concentrations decreased to basal values. When adrenaline was withdrawn there was no effect on plasma lactate but concentrations of FFA increased from approximately 5 to $7.5 \mathrm{mg} / 100 \mathrm{ml}$ at $30 \mathrm{~min}$. Thereafter values gradually declined.

Although no measurements were made of plasma adrenaline it might be expected that the infusion rate of adrenaline would have elevated plasma concentrations to values similar to those observed in surgical stress in humans (see Diebert \& de Fronzo, 1980).

Changes in plasma concentrations of insulin and growth hormone are depicted in Fig. 3. Initially, there was no change in plasma insulin even though plasma glucose concentrations had increased. By i h after commencing adrenaline infusions plasma insulin increased, but for the bulk of the infusion period values were not significantly different $(P>0.05)$ from those prior to adrenaline infusion.

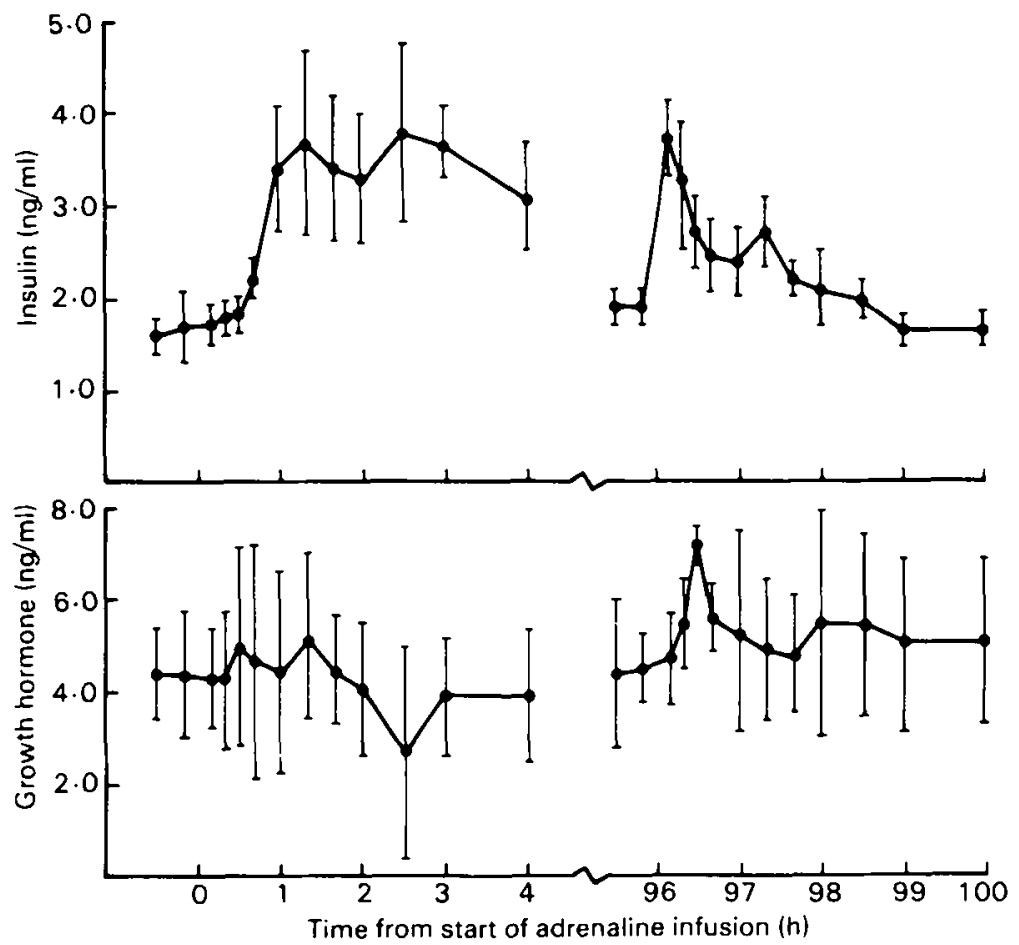

Fig. 3. Changes in plasma concentrations of insulin and growth hormone at the beginning and end of a period of $4 \mathrm{~d}$ over which adrenaline was infused intravenously at the rate of $0.05 \mu \mathrm{g} / \mathrm{kg}$ bodyweight per min. Values presented are means for four ewes and standard errors are shown as vertical bars. 
Immediately after withdrawal of adrenaline, insulin concentrations increased significantly $(P<0.05)$ from basal values of approximately 2 to $3.5 \mathrm{ng} / \mathrm{ml}$ by 10 min, then declined to basal values. No significant changes $(P>0.05)$ were measured for plasma growth hormone during adrenaline infusion but after withdrawal of adrenaline a significant increase $(P<0.05)$ was recorded by $30 \mathrm{~min}$.

The above changes in glucose kinetics, levels of blood metabolites and hormones are clearly in conformity with responses reported in humans and laboratory rodents (see Exton, 1979) as well as ruminants (Bassett, 1970, 1971, 1975; Sato, 1977; Graham \& Phillips, 1981). Thus, infusion of adrenaline increased glucose production and decreased its utilization. It seems reasonable to assert that this was the end result of a suppression of insulin secretion (and/or a lowering of the levels of 'effective insulin') together with promotion of gluconeogenesis directly and indirectly by way of enhanced glucagon secretion. The glycogenolytic and lipolytic effects of adrenaline were evident during the first hours of adrenaline infusion. The very high glucose production occurring during the first few hours of adrenaline infusion apparently resulted from increased glycogenolysis and gluconeogenesis. Subsequently, maintenance of enhanced glucose production (reflected by persistently high concentrations of plasma glucose) was probably due to enhanced gluconeogenesis together with a suppression of insulin.

Withdrawal of adrenaline removed the suppression of insulin with a resultant rapid increase in glucose utilization. It was of interest that concentrations of growth hormone as well as FFA increased. This growth hormone response may have occurred as a result of the rapid decline in plasma glucose and hence glucose availability. Interestingly, Reynaert $e t$ al. ( 1976 ) reported a significant, short-lived increase in plasma concentration of growth hormone after withdrawal of adrenaline infusions in cattle and they attributed the increase in growth hormone as a response to a sharp decrease in plasma FFA. Others have noted that growth hormone was released in response to rapid decreases in plasma glucose (Trenkle, 1971; Reynaert et al. 1972).

\section{Glucocorticoids}

Concentrations of glucocorticoids in plasma of cattle (Trenkle, I978; Trenkle \& Topel, 1978; Mills \& Jenny, 1979) and sheep (Sasaki et al. 1974) increase during fasting and intravenous infusion of glucose into fasted sheep decreases concentrations of plasma glucocorticoids (Sasaki et al. 1974). Furthermore, plasma concentrations of glucocorticoids increase during exercise in pregnant sheep (Bell et al. 1981), following cold exposure of lactating goats (Faulkner et al. 1980) and in response to behavioural stress in sheep (Cronin et al. 198I). These observed increases in plasma glucocorticoids in response to increased requirement for glucose suggest that they are involved in the maintenance of glucose homoeostasis.

In studies with fasted sheep, Bassett (1968) showed that daily intramuscular injections of cortisol increased concentrations of plasma glucose and diminished the increases in plasma FFA and ketone bodies observed in non-treated animals. In addition, there was an increased excretion of nitrogen in urine of the cortisol- 
treated sheep. When phloridzin (glucoside) was injected together with cortisol, the increase in plasma glucose was lessened, concentrations of ketone bodies, FFA and amino acid nitrogen in plasma increased, substantial amounts of glucose were excreted in urine and urinary-nitrogen excretion increased markedly. On the other hand, injections of insulin, as well as cortisol, abolished the hyperglycaemia and lessened the increase in plasma FFA, ketone bodies and amino acids.

The results of the above studies suggested that cortisol stimulated protein catabolism and gluconeogenesis in response to a decrease in blood glucose. The 'anti-lipolytic' and 'anti-ketogenic' effects of cortisol apparently were due to enhanced secretion of insulin. Indeed, Bassett \& Wallace (1967) demonstrated that cortisol enhances insulin secretion in sheep.

Studies by Reilly \& Black (1973) firmly established that cortisol has marked effects on protein catabolism in ruminants. They monitored glucose and alanine metabolism in adrenalectomized sheep treated with cortisol. An increase in plasma glucose concentration was observed and this was attributed to a decrease in peripheral utilization of glucose since glucose production was suppressed in cortisol-treated animals. Significantly, there was an increase in the incorporation of alanine carbon into glucose suggesting that cortisol treatment induced a preferential diversion of amino acids towards gluconeogenesis.

Additional evidence for glucocorticoids enhancing gluconeogenesis from amino acids was presented by Reilly \& Ford (1974). They monitored the effects of a single injection of betamethasone (glucocorticoid) on glucose production and incorporation of amino acids into glucose in sheep. There were substantial increases in plasma glucose, glucose entry rate and the fractional rate of incorporation of amino acid carbon into glucose $24 \mathrm{~h}$ after injection of betamethasone. There were, however, no significant changes in arterial concentrations of amino acids or entry rate of amino acids. Reilly \& Ford (1974) concluded that betamethasone caused a decrease in the net rate of release of amino acids from the liver due to increased uptake and utilization of amino acids as gluconeogenic substrates.

Recently, Baird (1981) summarized data showing the effects of glucocorticoid treatment of lactating dairy cows on carbohydrate status. Interestingly, treatment of ketotic cows with glucocorticoid reduced liver concentrations of ketone bodies but increased liver glycogen and lactate concentrations. These changes were interpreted as evidence that glucocorticoids increase plasma insulin which, together with a moderate hyperglycaemia, would promote glycogen synthesis in the liver and prevent mobilization of fatty acids from adipose tissue. Baird (r98I) also noted that glucocorticoids would tend to decrease milk output (thus sparing glucose) and increase mobilization of protein stores to provide amino acids as substrates for gluconeogenesis.

From the above it is apparent that glucocorticoids may exert effects on glucose homoeostasis in ruminants. Their effects on release of amino acids from muscle tissue appear to be similar to those occurring in humans and other species (see Exton, 1979). In spite of this, it seems that the glucocorticoids are not major short- 
term regulators of glucose homoeostasis in the ruminant (Bassett, 1975, 1978; Ely \& Baldwin, 1976). They may, however, be important for long-term regulation of energy supply (Trenkle, i 981 ).

\section{Chorionic somatomammotropin (placental lactogen)}

Grumbach et al. (1968) speculated that placental lactogen may be the 'growth hormone of pregnancy' in humans. It appears that, in the human, placental lactogen acts to regulate maternal metabolism to ensure an adequate supply of nutrients - particularly glucose-for the foetus. More specifically it seems that, in pregnant women, placental lactogen is lipolytic and has 'anti-insulin' activity. As a result of these effects plasma levels of FFA and glycerol are increased, proteolysis is promoted, effective concentrations of insulin in plasma decrease, glucose utilization decreases and gluconeogenesis is stimulated. These effects of placental lactogen are most apparent following fasting which is a potent stimulus for release of placental lactogen (Grumbach et al. 1973).

In view of these effects of human placental lactogen it is not surprising that researchers have sought to demonstrate similar effects of placental lactogen in ruminants. Results of studies in ruminants have been equivocal. On the one hand, Handwerger et al. (1976) reported significant decreases in blood concentrations of FFA and insulin by $\mathrm{I} h$ after injection of pregnant and non-pregnant ewes with a relatively pure preparation of placental lactogen. Moreover, significant decreases in the plasma concentrations of glucose and amino nitrogen were measured 3 and $6 \mathrm{~h}$ respectively after injection of placental lactogen.

Other workers have obtained results which may be interpreted as evidence that placental lactogen affects glucose homoeostasis in ruminants, and may be important for ensuring a supply of sufficient glucose to meet the requirements of the foetus(es).

In studies with pregnant goats, Hayden et al. $(\mathrm{x} 980)$ noted that during late pregnancy there was an inverse relationship between concentrations of placental lactogen and glucose in maternal plasma. Further, they reported a tendency for concentrations of FFA to increase as concentrations of placental lactogen increased.

More recently, Oddy \& Jenkin (1981) recorded interesting observations made on pregnant ewes given a variety of diets designed to provide a range of energy and nitrogen intakes. In their studies ewes were given throughout pregnancy either oaten chaff, lucerne chaff or a mixture of oaten and lucerne chaffs in the ratio 50:50. The data reported are summarized in Table 1 .

Interestingly, concentrations of placental lactogen in maternal plasma were highest in ewes given the poorest diet (oaten chaff) and for a given diet were higher for twin-bearing ewes than ewes bearing a single foetus. Furthermore, birth weights of single lambs were similar regardless of the diet given to the ewes, even though there were marked differences in changes in body-weights of ewes over the period of pregnancy. Although Oddy \& Jenkin (198I) were guarded in their 
Table 1. Average energy and nitrogen intakes, changes in maternal body-weight, birth weights of lambs and concentrations of placental lactogen in plasma on day 130 of pregnancy for mature Merino ewes bearing single or twin foetuses. Ewes were given either oaten chaff $(O C)$, lucerne chaff $(L C)$ or a mixture $\left(5^{\circ}: 5^{\circ}\right)$ of oaten and lucerne chaffs"

\author{
Energy intake (MJ ME/d) \\ Nitrogen intake $(\mathrm{g} / \mathrm{d})$ \\ Number of ewes \\ Change in body-weight between \\ conception and lambing $(\mathrm{kg})$ \\ Birth weight of lambs $(\mathrm{kg})$ \\ Placental lactogen $(\mu \mathrm{g} / \mathrm{ml})$
}

\begin{tabular}{ccccc} 
OC & \multicolumn{2}{c}{ OC:IC } & Diet & $\overbrace{\text { Single }}^{\text {LC }}$ \\
& $\overbrace{\text { Twins }}$ & Twins \\
6.1 & 10.6 & 10.6 & 13.5 & 13.5 \\
8.4 & 28.3 & 28.3 & 51.8 & 51.8 \\
5 & 3 & 4 & 5 & 4 \\
-0.6 & 7.5 & 6.5 & 11.9 & 9.7 \\
3.7 & 4.1 & $6.1 \dagger$ & 3.9 & $7.2 \dagger$ \\
3.9 & 1.5 & 2.5 & 0.9 & 2.2
\end{tabular}

-After Oddy \& Jenkin (1981).

tCombined weight of twins.

ME, Metabolizable energy.

conclusions they raised the possibility that placental lactogen may play a role in directing nutrients from mother to foetus.

The effects of inducing hyper- and hypoglycaemia in pregnant ewes and their foetuses on maternal and foetal concentrations of placental lactogen were reported recently by Brinsmead et al. (1981). Induction of hyperglycaemia by infusion of glucose into foetuses failed to affect concentrations of placental lactogen in foetal and maternal plasma. Similarly, infusion of insulin to induce hypoglycaemia in either the ewe or its foetus was without significant effects on concentrations of maternal and foetal placental lactogen. However, when pregnant ewes were fasted for several days there were decreases in concentrations of glucose in maternal and foetal plasma and concomitant dramatic increases in the concentrations of placental lactogen in plasma of both ewes and foetuses.

Brinsmead et al. ( $198 \mathrm{I}$ ) concluded that their results neither confirmed nor refuted a role for placental lactogen in intermediary metabolism of the pregnant ewe or its foetus and that glucose concentration alone was unlikely to be an important factor controlling the secretion of placental lactogen in the sheep. It seems reasonable to suggest that the infusions of glucose and insulin may have set in train homoeostatic mechanisms which prevented clear demonstration of effects of glucose on the control of secretion of placental lactogen. The responses to food deprivation provided a better illustration of the possible in vivo effects of placental lactogen on glucose homoeostasis.

Some years ago Leader (1975) proposed that during late pregnancy, when the ruminant mammary gland is differentiated, milk biosynthesis is prevented by the 'anti-insulin effect' of placental lactogen on carbohydrate metabolism. Although 
this proposal was not supported by experimental data (nor has been since) it is an interesting one. The large requirement for glucose of the lactating mammary gland (Annison et al. r974; Hardwick et al. 1974) would certainly interfere with an adequate supply of glucose to support foetal requirements.

Clearly, firm conclusions cannot be drawn regarding the role of placental lactogen in glucose homoeostasis in the ruminant. Evidence for placental lactogen affecting glucose homoeostasis is merely circumstantial. None the less, available results are consistent with such a role. Receptors for placental lactogen have been identified in sheep adipose tissue (Chan et al. 1978) and promotion of lipolysis would provide glycerol for gluconeogenesis and FFA, which could act as alternative substrates for oxidative metabolism thus sparing glucose. There is compelling evidence that concentrations of placental lactogen in ruminants increase in response to undernutrition (Brinsmead et al. 1981; Oddy \& Jenkin, I981) and concentrations of placental lactogen are higher in the plasma of pregnant goats (Hayden et al. I980), and sheep (Oddy \& Jenkin, I98I) bearing multiple rather than single foetuses. Demonstration of a role for placental lactogen must await successful isolation of sufficient quantities of purified ruminant placental lactogen which retains its biological activities. To date, researchers have met with difficulties in their attempts to purify ruminant placental lactogen.

\section{Other hormones}

There is evidence that thyroid hormones may participate in control of glucose homoeostasis, even if only indirectly, by altering metabolic rate. A number of workers have reported that concentrations of thyroid hormones in plasma are inversely related to milk production in dairy cows (Hart et al. 1978; 1979; Walsh et al. 1980). Concentrations of thyroid hormones are lower for cows given restricted rather than adequate amounts of energy (Kunz et al. $198 \mathrm{I}$ ) and in lactating sheep concentrations of thyroid hormone are reduced by feed restriction (Gow et al. 1981). Moreover, concentrations of thyroid hormones are reduced during compensatory growth in cattle (Fox et al. 1974) and also in cattle in which growth has been promoted using anabolic steroids (Heitzman et al. 1977; Donaldson et al. I98I). Interestingly, there is evidence that thyroxine stimulates hepatic gluconeogenesis and ketogenesis in dairy cows (Heitzman et al. 1971).

Circumstantial evidence that progesterone may affect glucose homoeostasis by virtue of its effects on insulin has been obtained from studies with rats (Sutter-Dub et al. 1973). In these studies it was observed that although plasma insulin was increased during late pregnancy the concentrations of glucose were unaffected. This was interpreted as evidence that progesterone may antagonize the effects of insulin. This postulated role of progesterone in antagonizing insulin does not appear to have been confirmed and recent observations raise the possibility that placental lactogen may lower concentrations of 'effective insulin' during pregnancy.

Recently, Bauman \& Currie (1980) discussed the very equivocal evidence that prolactin may have indirect effects on glucose homoeostasis by virtue of its effects 


\section{Vol. 42 Nutrient-hormone interactions in animal production}

on adipose tissue and possibly hypertrophy of the gastrointestinal tract. These reviewers cited evidence from studies with rodents and circumstantial evidence from ruminant studies which might be interpreted to implicate prolactin in participating in the control of glucose homoeostasis. None the less, Bauman \& Currie ( 1980 ) pointed out that it was not possible to draw firm conclusions from available results.

During recent years there has been intense interest in the regulation of secretion of insulin and glucagon by a series of gut hormones and by somatostatin. Brief mention will be made of these hormones in view of the key roles of insulin and glucagon in maintaining glucose homoeostasis.

There is good evidence from studies in nonruminants that a number of hormones secreted by the gut musoca affect secretion of both insulin and glucagon (see Bloom, 1981; Dobbs, I98I). Apparently secretin, cholecystokinin, gastric inhibitory peptide and gastrin stimulate the secretion of glucagon and gastrin, and cholecystokinin and gastric inhibitory peptide promote insulin secretion. Although data on the effects of gastrointestinal hormones on insulin and glucagon secretion in ruminants are scant, available data suggest similar effects in ruminant species. Indeed, there are reports that insulin secretion in ruminants may be stimulated by cholecystokinin and secretin (see Bassett, 1975; Brockman, 1978).

Enteroglucagon is another gut hormone which may affect glucose homoeostasis in ruminants. Berzins \& Manns (1979) observed that plasma concentrations of enteroglucagon increased as the proportion of grain in the rations of dairy cows increased. This observation led them to raise the possibility that enteroglucagon may act as a partial inhibitor of glucagon and thus reduce the rate of gluconeogenesis when rations containing high proportions of concentrates are fed. More recently, A. W. Bell, J. M. Bassett, K. D. Chandler and R. C. Boston (unpublished results) measured changes in enteroglucagon in response to exercise in pregnant ewes. Significantly, exercise induced a substantial reduction in plasma enteroglucagon and it was suggested that this reduction in enteroglucagon (together with a reduction in plasma insulin) might be important for facilitating increased glucose production.

Somatostatin (secreted by the ' $D$ cells' of the pancreas) exerts wide-ranging effects in nonruminants including inhibition of the secretion of the gut hormones as well as both insulin and glucagon (Rizza \& Gerich, I98I; Unger \& Orci, r98I). Results from recent studies with sheep suggest that somatostatin may exert similar effects, at least on insulin and glucagon secretion, in ruminants as it does in nonruminants (Brockman \& Greer, I980; Brockman \& Halvorson, 1981).

\section{Models for studying hormonal control of glucose homoeostasis}

The dramatic increases in the requirements for glucose of pregnant and lactating ruminants (see Table 2) makes it feasible to use animals in these physiological states for studying the control of glucose homoeostasis. During recent years researchers have appreciated the usefulness of the pregnant/lactating ewe for 
Table 2. Glucose biokinetic results for seven Border Leicester $\times$ Merino ewes before pregnancy, at $\mathrm{1}^{\circ} \mathrm{O}$ of pregnancy and during the first week of lactation*

(Mean values with their standard errors)

\begin{tabular}{|c|c|c|c|c|c|c|}
\hline & \multicolumn{2}{|c|}{ Non-pregnant } & \multicolumn{2}{|c|}{ Pregnant } & \multicolumn{2}{|c|}{ Lactating } \\
\hline & Mean & $\mathrm{SE}$ & Mean & SE & Mean & SE \\
\hline Plasma glucose $(\mathrm{mg} / \mathrm{ml})$ & 0.70 & 0.01 & 0.66 & 0.02 & 0.60 & 0.02 \\
\hline Glucose pool size $\left(\mathrm{mg} / \mathrm{kg} \mathrm{W}^{0.79}\right)$ & 310 & 7 & 320 & I I & 337 & 22 \\
\hline $\begin{array}{l}\text { Glucose irreversible loss } \\
\left(\mathrm{mg} / \mathrm{min} \text { per } \mathrm{kg} \mathrm{W} \mathrm{W}^{0.75}\right) \\
(\mathrm{g} / \mathrm{d}) \\
\text { Milk yield }(\mathrm{g} / \mathrm{d})\end{array}$ & $\begin{array}{c}5 \cdot 3 \\
\mathbf{1} 3^{8} \\
-\end{array}$ & $\begin{array}{c}0.4 \\
11 \\
-\end{array}$ & $\begin{array}{c}7^{72} \\
203^{-} \\
\end{array}$ & $\begin{array}{c}0.4 \\
15 \\
\end{array}$ & $\begin{array}{r}7 \cdot 3 \\
183 \\
1169\end{array}$ & $\begin{array}{c}0.6 \\
19 \\
198\end{array}$ \\
\hline
\end{tabular}

- After C. B. Gow, G. H. McDowell and E. F. Annison, unpublished results.

studies of this nature and brief mention will be made of two recent studies in ewes to illustrate their suitability.

Gow et al. (198r) submitted lactating ewes to a dramatic reduction in feed intake and examined hormonal changes associated with attempts to maintain glucose supply. Reduction in food intake by $80 \%$ resulted in significant reductions in body-weight, milk yield, plasma glucose, glucose pool size, irreversible loss of glucose and blood concentrations of most glucogenic amino acids but concentrations of FFA in plasma increased. Concentrations of plasma insulin and thyroxine decreased whereas plasma glucagon remained relatively unaffected and concentrations of growth hormone increased. As a result of these changes the ratio of insulin:growth hormone decreased and there was also a dramatic decrease in the molar ratio of insulin:glucagon (see Fig. I). These changes in plasma concentrations of hormones were consistent with the need to maintain plasma glucose in response to the dramatic reduction in feed intake.

Changes in plasma metabolites and hormones in response to exercise in late-pregnant ewes were monitored recently by $A$. W. Bell and co-workers (unpublished results). It was found that exercise induced rapid increases in concentrations of both glucose and lactate in maternal plasma. These changes were accompanied by substantial increases in plasma concentrations of pancreatic glucagon and glucocorticoids (cortisol) and significant decreases in growth hormone and enteroglucagon, but there was no change in insulin (resulting in a substantial decrease in the molar ratio of insulin:glucagon). The changes in plasma hormones were consistent with glucagon and cortisol having major roles in the maintenance of glucose homoeostasis.

Studies of the nature of those outlined above provide valuable information on the hormonal control of glucose homoeostasis in the ruminant. Available evidence from these studies (and also other studies referred to previously) indicates that the hormonal control of glucose homoeostasis in the ruminant is effected by a complex interplay of hormones similar to that occurring in other species. 


\section{REFERENCES}

Annison, E. F., Bickerstaffe, R. \& Linzell, J. L. (1974). F. agric. Sci. Camb. 82, 87.

Baird, G. D. (1981). Fedn Proc. Fedn Am. Soc. exp. Biol. 40, 2530.

Bassett, J. M. (1968). Metabolism 17,644.

Bassett, J. M. (1 970). Aust. F. biol. Sci. 23, 903.

Bassett, J. M. (1971). Aust. F. biol. Sci. 24, 31 1.

Bassett, J. M. (1974). Aust. F. biol. Sci. 27, 167.

Bassett, J. M. (1975). In Digestion and Metabolism in the Ruminant, p. 383 [1. W. McDonald and A. C. I. Warner, editors]. Armidale: University of New England Publishing Unit.

Bassett, J. M. (1 978). Proc. Nutr. Soc. 37, 273.

Bassett, J. M. (1983). Proc. Nutr. Soc. 42, 34A, 35A, 40 A.

Bassett, J. M. \& Wallace, A. L. C. (1966). Metabolism 15, 933.

Bassett, J. M. \& Wallace, A. L. C. (1967). Diabetes 16, 566.

Bassett, J. M., Weston, R. H. \& Hogan, J. P. (1971). Aust. J. biol. Sci. 24, 321.

Bauman, D. E. \& Currie, W. B. (I980). Y. Dairy Sci. 63, I 5 I 4.

Bell, A. W., Chandler, K. D. \& Bassett, J. M. (1981). Proc. Nutr. Soc. Aust. 6, 108.

Bergman, E. N. (1973). Cornell Vet. 37, 341.

Berzins, R. \& Manns, J. G. (1979). F. Dairy Sci. 62, 739.

Bines, J. A. \& Hart, I. C. (1977). In Blood Profiles in Animal Production, p. 87 [D. Lister, editor]. Occasional Publication No. 1 of the British Society of Animal Production.

Bines, J. A., Hart, I. C. \& Morant, S. V. (1980). Br. F. Nutr. 43, I 79.

Bird, A. R., Chandler, K. D. \& Bell, A. W. (1981). Aust. F. biol. Sci. 34, 54 I.

Bloom, S. R. (198I). In Glucagon, Physiology, Pathophysiology and Morphology of the Pancreatic A-cells, p. 99 [R. H. Unger and L. Orci, editors]. New York and Oxford: Elsevier North Holland Inc.

Brinsmead, M., Bancroft, B. J., Thorburn, G. D. \& Waters, M. J. (1981). F. Endocr. 90, 337.

Brockman, R. P. (1978). Can. Vet. J. 19, 55.

Brockman, R. P. \& Greer, C. (1980). Aust. F. biol. Sci. 33, 457.

Brockman, R. P. \& Halvorson, R. (1981). Aust. Y. biol. Sci. 34, 551.

Chan, J. S. D., Robertson, H. A. \& Friesen, H. G. (1978). Endocrinology 102, 632.

Cowan, J. S. \& Hetenyi, G. (197I). Metabolism 20, 360.

Cronin, M. T., Siegel, B. J. \& Moberg, G. P. (198r). Physiol. Behav. 26, 887.

de Bodo, R. C., Steele, R., Altszuler, N., Dunn, A. \& Bishop, J. S. (1969). Recent Prog. Horm. Res. I9, 445 .

Diebert, D. C. \& de Fronzo, R. A. (1980). F. clin. Invest. 65, 717.

Dobbs, R. E. (1981). In Glucagon, Physiology, Pathophysiology and Morphology of the Pancreatic A-cells, p. I 5 [R. H. Unger and L. Orci, editors]. New York and Oxford: Elsevier North Holland Inc.

Donaldson, I. A., Hart, I. C. \& Heitzman, R. J. (1981). Res. Vet. Sci. 30, 7 .

Dracy, A. E. \& Jordan, R. M. (1954). F. Anim. Sci. 13, 1018.

Driver, P. M., Adams, G. B. \& Forbes, M. (1979). F. Endocr. 83, 50 P.

Driver, P. M. \& Forbes, J. M. (1978). Proc. Nutr. Soc. 37, $100 A$.

Ely, L. O. \& Baldwin, R. L. (1976). J. Dairy Sci. 59, 491.

Exton, J. H. (1979). In Hormones and Energy Metabolism, p. 125 [D. M. Klachko, R. R. Anderson and $M$. Heimberg, editors]. New York and London: Plenum Press.

Faulkner, A., Thompson, E. M., Bassett, J. M. \& Thomson, G. E. (1980). Br. J. Nutr. 43, 163.

Felig, P., Sherwin, R. S., Soman, V., Wahren, J., Hendler, R., Sacca, L., Eigler, N., Goldberg, D. \& Walesky, M. (1979). Recent Prog. Horm. Res. 35, $50 \mathrm{I}$.

Forbes, J. M., Driver, P. M., Brown, W. B., Scanes, C. G. \& Hart, I. C. (1979). Anim. Prod. 29, 43.

Fox, D. G., Preston, R. L., Senft, B. \& Johnson, R. R. (1974). F. Anim. Sci. 38, 437.

Gow, C. B., McDowell, G. H. \& Annison, E. F. (1981). A Ast. F. biol. Sci. 34, 469.

Graham, A. D. \& Phillips, G. D. (1981). Can. F. Anim. Sci. 61, 919.

Grumbach, M. M., Kaplan, S. L., Sciarra, J. J. \& Burr, I. M. (1968). Ann. N.Y. Acad. Sci. 148, 5 or. 
Grumbach, M. M., Kaplan, J. L. \& Vinik, A. (1973). In Methods in Investigative and Diagnostic Endocrinology. Peptide Hormones. vol. 2B, part IIIA. Non-pituitary Hormones, pp. 797 and 810. [S. A. Berson, editor]. Amsterdam: North-Holland Publishing Co.

Handwerger, S., Fellows, R. E., Crenshaw, M. C., Hurley, T., Barrett, J. \& Maurer, W. F. (1976). 7. Endocr. 69, I33.

Hardwick, D. C., Linzell, J. L. \& Mepham, T. B. (1974). Biochem. f. 88, 213.

Hart, I. C., Bines, J. A., Cowie, A. T. \& Balch, C. C. (1975). Y. Endocr. 65, 3 P.

Hart, 1. C., Bines, J. A. \& Morant, S. V. (1979). F. Dairy Sci. 62, 270.

Hart, I. C., Bines, J. A. \& Morant, S. V. (1980). Life Sci. 27, 1839.

Hart, I. C., Bines, J. A., Morant, S. V. \& Ridley, J. L. (1978). Y. Endocr. 77, 333.

Hart, I. C., Flux, D. S., Andrews, P. \& McNeilly, A. S. (1975). Horm. Metab. Res. 7, 35.

Hart, I. C., Lawrence, S. E. \& Mepham, T. B. (1980). Y. Physiol. 308, 46 P.

Hayden, T. J., Thomas, C. R., Smith, S. V. \& Forsyth, I. A. (1980). F. Endocr. 86, 279.

Heitzman, R. J., Chan, K. H. \& Hart, I. C. (1977). Br. Vet. $\mathcal{F} .133,62$.

Heitzman, R. J., Hibbitt, K. G. \& Mather, I. (I971). Eur. F. Biochem. 2 1, 41 I.

Hertelendy, F. \& Kipnis, D. M. (I 973). Endocrinology 92, 402.

Hove, K. \& Blom, A. K. (1973). Acta Endocr. 73, 289.

Jordan, R. M. \& Shaffhausen, D. D. (1954). F. Anim. Sci. 13, 706.

Kunz, P., Blum, J. W. \& Hart, I. C. (198r). Int. J. Vit. Nutr. Res. 51 , 195.

Leader, D. P. (1975). Biochem. Soc. Trans. 3, 257.

Lindsay, D. B. (1959). Vet. Rev. Annot. 5, 103.

Lindsay, D. B. (1978). Biochem. Soc. Trans. 6, I 152.

Lindsay D. B. (1980). In Hormones and Metabolism in Ruminants, p. 25 [J. M. Forbes and M. A. Lomax, editors]. London: Agricultural Research Council.

Machlin, L. J. (1973). F. Dairy Sci. 56, 575 .

Machlin, L. J. (1976). In Anabolic Agents in Animal Production, p. 43, [F. C. Lu and J. Rendel, editors]. Stuttgart: Georg Thieme.

Mepham, T. B., Lawrence, S. E. \& Hart, I. C. (1983). Horm. Metab. Res. (In the Press.)

Mills, S. E. \& Jenny, B. F. (1979). F. Anim. Sci. 48, 961 .

Oddy, V. H. \& Jenkin, G. (1981). Proc. Nutr. Soc. Aust. 6, 151.

Peel, C. J., Bauman, D. E., Gorewit, R. C. \& Smiffen, C. J. (1981). F. Nutr. 111 , 1662.

Pethick, D. W. \& Lindsay, D. B. (1981). Proc. Nutr. Soc. Aust. 6, 105.

Reilly, P. E. B. \& Black, A. L. (1973). Am. F. Physiol. 225, 689.

Reilly, P.E. B. \& Ford, E. J. H. (1974). F. Endocr. 60, 455.

Reynaert, R., de Paepe, M. \& Peeters, G. (1972). Int. Arch. Pharm. Ther. 197, 405.

Reynaert, R., Marcus, S., de Paepe, M. \& Peeters, G. (1976). Horm. Metab. Res. 8, rog.

Rizza, R. A. \& Gerich, J. E. (198I). In Glucagon, Physiology, Pathophysiology and Morphology of the Pancreatic A-cells, p. 377 [R. H. Unger and L. Orci, editors]. New York and Oxford: Elsevier North Holland, Inc.

Sasaki, Y., Kumazaki, K. \& Ikeda, O. (1974). Fap. F. Zootech. Sci. 45, 81.

Sato, H. (1977). Fap. F. Zootech. Sci. 48, 610.

Steele, R. (1959). Ann. N.Y. Acad. Sci. 82, 420.

Steele, R., Wall, J. S., de Bodo, R. C. \& Altszuler, N. (1956). Am. F. Physiol. 187, 15.

Sutter-Dub, M.-Th., Leclercq, R., Felix, J. M., Jacquot, R. \& Sutter, B.Ch. J. (1973). Horm. Metab. Res. 5, i 8.

Tindal, J. S., Blake, L. A., Simmonds, A. D., Hart, I. C. \& Mizuno, H. (1982). Horm. Metab. Res. 14,525 .

Tindal, J. S., Knaggs, G. S., Hart, I. C. \& Blake, L. A. (1978). J. Endocr. 76, 333.

Trenkle, A. (1970). F. Anim. Sci. 32, i i .

Trenkle, A. (1971). Proc. Soc. exp. Biol. Med. 136, 5 I.

Trenkle, A. (1978). F. Dairy Sci. 6r, 28r.

Trenkle, A. (1981). Fed. Proc. 40, 2536.

Trenkle, A. \& Topel, D. G. (1978). F. Anim. Sci. 46, 1604.

Unger, R. H. (1971). Diabetes 20, 834 .

Unger, R. H. \& Orci, L. (1981). In Glucagon, Physiology, Pathophysiology and Morphology of the Pancreatic $A$-cell, p. I6r [R. H. Unger and L. Orci, editors]. New York and Oxford: Elsevier North Holland Inc. 
Vernon, R. G. (1 978). Biochem. Soc. Trans. 6, 988.

Wall, J. S., Steele, R., de Bodo, R. C. \& Altszuler, N. (1957). Am. F. Physiol. 189, 43.

Wallace, A. L. C. \& Bassett, J. M. (1966). Metabolism 15, 95.

Walsh, D. S., Vesely, J. A. \& Mahadevan, S. (1980). F. Dairy Sci. 63, 290. 